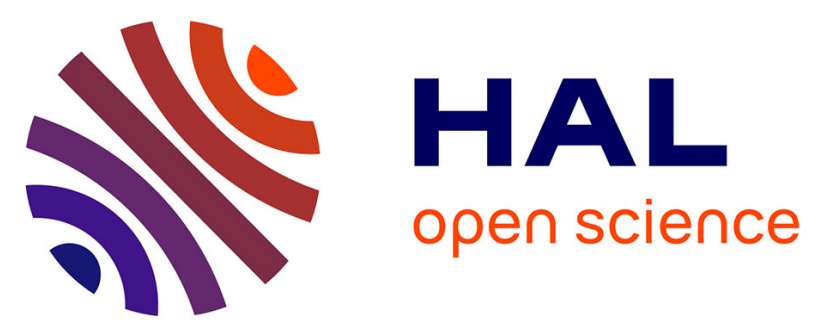

\title{
Structure and functional characteristics of the meiofauna community in highly unstable intertidal mudbanks in Suriname and French Guiana (North Atlantic coast of South America)
}

Christine Dupuy, Hien Thanh Nguyen, David Mizrahi, Jérôme Jourde, Martine Bréret, Hélène Agogué, Laureen Beaugeard, Pierrick Bocher

\section{To cite this version:}

Christine Dupuy, Hien Thanh Nguyen, David Mizrahi, Jérôme Jourde, Martine Bréret, et al.. Structure and functional characteristics of the meiofauna community in highly unstable intertidal mudbanks in Suriname and French Guiana (North Atlantic coast of South America). Continental Shelf Research, 2015, 10.1016/j.csr.2015.09.019 . hal-01243550

\author{
HAL Id: hal-01243550 \\ https://hal.science/hal-01243550
}

Submitted on 15 Dec 2015

HAL is a multi-disciplinary open access archive for the deposit and dissemination of scientific research documents, whether they are published or not. The documents may come from teaching and research institutions in France or abroad, or from public or private research centers.
L'archive ouverte pluridisciplinaire HAL, est destinée au dépôt et à la diffusion de documents scientifiques de niveau recherche, publiés ou non, émanant des établissements d'enseignement et de recherche français ou étrangers, des laboratoires publics ou privés. 
Structure and functional characteristics of the meiofauna community in highly unstable intertidal mudbanks in Suriname and French Guiana (north Atlantic coast of South America)

Dupuy Christine ${ }^{\mathrm{a},{ }^{*} \text {, Nguyen Thanh Hien }}{ }^{\mathrm{a}}$, Mizrahi David ${ }^{\mathrm{b}}$, Jourde Jérôme ${ }^{\mathrm{a}}$, Bréret Martine $^{\mathrm{a}}$, Agogué Hélène ${ }^{\mathrm{a}}$, Beaugeard Laureen ${ }^{\mathrm{a}}$, Bocher Pierrick ${ }^{\mathrm{a}}$

${ }^{a}$ Littoral, Environnement et Sociétés (LIENSs) UMR 7266 CNRS - Université de La Rochelle, 2 Rue Olympe de Gouges, 17000, La Rochelle, France

${ }^{\mathrm{b}}$ New Jersey Audubon Society, 600 Route 47 North, Cape May Court House, NJ 08210, USA

*Corresponding author: e-mail address: cdupuy@ univ-lr.fr (C. Dupuy) 
Keywords:French Guiana,Suriname, unstable intertidal mudbanks, chlorophyll $a$, organic matter content, prokaryotes, meiofauna 


\section{Abstract}

The north Atlantic coast of South America is influencedby the Amazon River. This coast is considered the muddiest in the world due to the enormous suspended sediment input from the Amazon River. The mobility of the sediment imposes a geomorphological dynamic with a rapid change of shoreline and fast alternation of facies types of the sediment. This study first describes the spatial and functional structure of meiofauna communities of highly unstable intertidal flats along coasts of French Guiana and Suriname in relation to environmental variables. Six sampling sites, composed mainly of muddy sediment, were located $700 \mathrm{~km}$ (Kourou) to $1200 \mathrm{~km}$ (Nickerie) from the mouth of the Amazon River. The granulometry, chlorophyll a biomass, prokaryote abundance, percentage of organic matter,meiofauna abundance and feeding guilds of nematodes in sediment stations were independent of the distance of the Amazon River mouth and likely were more influenced by the local dynamism of migration of mudbanks.Meiofauna was not more abundant when the sediment was dominatedby the finest sediment particles and also when chlorophyll $a$ and prokaryotes, potential prey of meiofauna, were greater. However, as a percentage, small nematodes (biomass of $0.07 \pm 0.001 \mu \mathrm{g}$ ind $^{-1}$ ), which are mainly epigrowth-feeders, were more abundant in very fluid mud. Local granulometry and organic matter content appearedto bedriving factors of the size structure and functional characteristics of nematodes. Despite the high instability of mudflats,chlorophyll $a$ biomass and meiofauna abundance always tended to be higher toward other world areas. No foraminifera among the six stations of the study were found. Very fluid mud with physical instability of sediment caused a large perturbation to the settlement of meiofauna; the least amounts of chlorophyll $a$ biomass and prokaryotic and meiofauna abundances were found there. Thus, the probable mobility of sediment may select for smaller meiobenthic organisms, mainly epigrowth-feeders nematodes, and disturb the 
larger organisms in the sediment, and, therefore, they would not permit the settlement of the foraminifera. In addition, no non-permanent meiofauna largely was found in the sediment. 


\section{Introduction}

The coast between the Amazon and Orinoco Rivers $(1500 \mathrm{~km})$ in South Americais considered the muddiest in the world due tothe enormous suspended sedimentinput from the AmazonRiver(754 Mty $^{-1} \pm 9 \%$ ) (Martinez et al., 2009). Thus, a large amount of fluid mud is transported from the Amazon River mouth in a north-western directionalong the coasts of the Guianas, includingFrench Guiana and Suriname, by a complex interaction of waves, tidal forces, and coastal currents. These complex interactions result in the formation of a series of large mudbanks that are distributed in at least 15 units $10-60 \mathrm{~km}$ long and $20-30 \mathrm{~km}$ wide and migrate $1 \mathrm{kmy}^{-1}$ (Allison et al.,2000). They impose a geomorphological dynamic leading to rapid changes of shoreline and fast alternation of facies type (Anthony et al., 2010). The intertidal area, bordered by mangroves,representsapproximately $5 \%$ of the entire mudbank.Although these emerged mudflats are unique in the world considering their high dynamic processes and particular instability, thediversity and structure of communities as well as food web functionality associated with these mudbanks are mostly unknown.

Intertidal soft sediment habitats rank among the most productive ecosystems on Earth, largely owing to the primary production of highly diverse assemblages of benthic diatoms (Underwood and Kromkamp, 1999). Indeed, at every low tide, the intertidal flats are rapidly covered by mats of microalgae (microphytobenthos[MPB])(Underwood and Kromkamp, 1999). Diatoms have the ability to migrate through fine sediments according to the tidal and daily irradiation cycles in order tofind optimal light conditions for their growth. The MPB constitutes a complex biofilm in association with prokaryotic communities, mainly composed of bacteria in the sediment surface (van Duyl et al., 1999). These prokaryotes play a fundamental role through the degradation and remineralisation of nutrients. The components of biofilm(MPB and prokaryotes)are considered key ecosystem engineers in food webs. In 
addition, diatoms are known to be important trophic sources for many benthic organisms (meiofauna and macrofauna), and the prokaryotes can represent a complementary food source for meio- and macrofauna (Moens and Vincx, 1997; Pascal et al., 2008a, b; Pascal et al., 2009).

Meiobenthos occurs in all types of sediments and is thus able to reside in a wide variety of habitats (subtidal and intertidal areas). Nevertheless, the texture of the sedimentis an important variable for structure and composition of meiobenthic assemblages (Schwinghamer, 1981; Semprucci et al., 2010; 2011). Abundance of benthic organisms is generally higher toward fine grains due to a concomitant increase of food availability (Balsamo et al., 2010; Heip et al., 1992). Meiofauna is generally considered to constitute recurrent taxa, such as nematodes, copepods, and foraminifera, and non-permanent taxa,such assmall gastropods, small bivalves, and small annelids. In mudflats, nematodes are consistently considered the most abundant meiobenthic taxa (Boucher and Lambshead, 1995). Some authors have suggested that the ecological significance of nematodes is crucial in terms of foodweb relationships (reviewed in Balsamo et al., 2012; Heip et al., 1985; Platt and Warwick, 1980), production of detritical organic matter, and recycling of nutrients, thereby enriching the coastal waters to support marine benthic production. Nematodes are functionally diverse, as they can beherbivores, bacterivores, depositfeeders, epigrowth feeders, orpredators (Pascal et al., 2008b; Rzeznik-Orignac et al., 2003).

The spatial structure of meiofauna assemblageshas been wellstudied in temperate mudflats (Pascal et al., 2008b; Rzeznik-Orignac et al., 2003) and tropical mangrove areas (Alongi, 1987; Chinnadurai and Fernando, 2007; Debenay et al., 2002; Xuan et al., 2007). Nevertheless, studies of bare tropical mudflat meiofauna are scarce and completely absent for the Guiana coast areas submitted to high dynamic processes, leading to a strong instability rarely met among coastal ecosystems. 
The present study first describes the spatial and trophic functional structure of meiofauna communities ofintertidal flats along the French Guiana and Suriname coasts in relation toenvironmental variables such as granulometry, chlorophyll $a$ biomass, prokaryote abundance, and percentage of organic matterin sediment.The sampling stations areinfluencedby the Amazon flume, considered the largest and muddiest river in the world, and the choice of the stations presented a gradient of influence of the river from east to west (from French Guiana to Suriname). Second, three types ofmud facies(fluid mud, moderately compacted mud, and compacted mud) were sampled on theintertidal mudflatsof Awala (French Guiana),and their meiofauna communities were compared.We hypothesised that in highly unstable intertidal mudbanks:

1) Compositions and abundances of meiofauna were different according to the grain size and particularly the fraction of fine sediment particles

2) Meiofauna was more abundantwhen MPB biofilm containing diatoms and prokaryotes, which are potential prey for meiofauna, was more abundant.

\section{Materials and methods}

\subsection{Study sites}

The intertidal mudflatsstudied are located along theFrench Guianese coast in front of the city of Kourou and village of Awala-Yalimapo and onthe Surinamese coastnear the village of Warappa and city of Nickerie (Fig. 1). All stations were sampled in April 2012 (wet season) at low tide in the upper area of the intertidal mudflats. The tides of the considered coast sections are semidiurnal with a tidal range of $0.8 \mathrm{~m}$ (neap tides) to $2.9 \mathrm{~m}$ (spring tides).

The median sediment grain size was characterised using a Malvern Mastersizer 2000 (Malvern Instruments, Ltd., UK) (size range $0.02-2000 \mathrm{~mm}$ ). This analysis allowed definition of different sediment textural groups by the relative abundance (percent volume) of mud 
(diameter $<63 \mu \mathrm{m}$ ) and sand (diameter between 63-2000 $\mu \mathrm{m}$ ) according to the UddenWentworth scale. Data processing was performed using the GRADISTAT program (Blot and Pye, 2001).

The sampled mudflat at Kourou $\left(05^{\circ} 10^{\prime} 40.45^{\prime \prime}\right.$; $\left.52^{\circ} 38^{\prime} 53.74 " \mathrm{~W}\right)$ is the closest study site to the Amazon River mouth at a distance of $700 \mathrm{~km}$ (Fig. 1). At Kourou, one station was sampled (Table 1).TheAwala mudflat station is located $850 \mathrm{kmfrom}$ the AmazonRiver mouth (Fig. 1). On this mudflat, contrary to other sites, samples were collected at three stations along a transect parallel to the coastline, presenting an alternation of facies type: Station A (St A) $\left(05^{\circ} 44^{\prime} 44.6 " \mathrm{~N} ; 53^{\circ} 55^{\prime} 36.2^{\prime \prime} \mathrm{W}\right)$, with very fluid mud (very soft mud); Station B (St B) $\left(05^{\circ} 44^{\prime} 44.7^{\prime \prime} \mathrm{N} ; 53^{\circ} 55^{\prime} 07.2^{\prime \prime} \mathrm{W}\right)$, with moderately compacted mud (soft mud) and Station C (St C) $\left(05^{\circ} 44^{\prime} 44.6^{\prime \prime N} ; \quad 53^{\circ} 54^{\prime} 57.8^{\prime \prime} \mathrm{W}\right)$, with compacted mud just before young mangroves.Warappa and Nickerie are located $1000 \mathrm{~km}$ and $1200 \mathrm{~km}$ from the Amazon River mouth, respectively (Fig. 1). One station per site was sampled at Warappa (soft mud) $\left(05^{\circ} 59^{\prime} 32.9^{\prime \prime} \mathrm{N} ; 54^{\circ} 55^{\prime} 50.1^{\prime \prime} \mathrm{W}\right)$ and at Nickerie (soft mud) $\left(05^{\circ} 59^{\prime} 09.9^{\prime \prime} \mathrm{N} ; 56^{\circ} 53^{\prime} 03^{\prime \prime} \mathrm{W}\right)$.

For each triplicate sample, the top 2-cm layers from three $15-\mathrm{cm}$ diameter cores were sliced and gathered together.Each sediment samplewas homogenised directly in the field in a sterile box and was subdivided for further analysis (storage conditions differed according to parameters).

\subsection{Environmental parameters}

Organic matter content (OM) (weight loss after incineration) of the sediment was estimated by weight loss at $450^{\circ} \mathrm{C}$ for $24 \mathrm{~h}$ (Wollast, 1989) from three replicated cores (deep frozen for later analysis).The OM was expressed as the percentage of total matter.

Three replicated coreswere used for algal biomass determination, which was assessed using chlorophyll $a(\mathrm{Chl}$ a) as a proxy and measured using fluorometry (640 nm, Turner TD 700, Turner Designs, USA) according to the method of Lorenzen (1966).Extraction of Chl 
awas obtained using freeze-dried sediment extracted at night in darknessin $4^{\circ} \mathrm{C}, 90 \%$ acetone and centrifuged $\left(10 \mathrm{~min}, 3500 \mathrm{~g}, 8^{\circ} \mathrm{C}\right)$. The $\mathrm{Chl}$ a biomasswas expressed as $\mu \mathrm{g} \mathrm{g}^{-1}$ dry weight

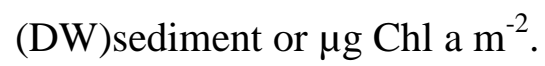

Heterotrophic prokaryotic abundance (PA) was quantified by flow cytometry according to Lavergne et al. (2014). Sub-samples of the top $2 \mathrm{~cm}$ of the sediment were fixed with $0.2-\mu \mathrm{m}$ filtered formaldehyde (vol/vol) (2\% final concentration) and stored at $4^{\circ} \mathrm{C}$ up to 3 months before analysis. Thawed samples were homogenised, prepared, and analysed as follows: 1) Sample preparation and extraction: dilution (1:1000-1:2000) in a detergent mix (sodium pyrophosphate $[0.01 \mathrm{M}]+$ Tween $80[0.1 \%]$ ), vortexing step, and $30 \mathrm{~min}$ of incubation at $4{ }^{\circ} \mathrm{C}$. After the vortexing step, a sonication separation for $30 \mathrm{~s}(60 \mathrm{~W})$ in ice with a sonication probe $(3 \mathrm{~mm})$ was applied. An aliquot of the sample was stained with SYBRGreen I (1:10000) for $15 \mathrm{~min}$ in the dark and analysed by flow cytometry (see analysis details below); and 2) the remaining part of the sample was centrifuged at low speed (1 min at $1000 \mathrm{~g}$ at $4^{\circ} \mathrm{C}$ ). The pellet was then resuspended in the detergent mix, and step 1 was repeated once. Each sample was analysed for $30 \mathrm{~s}$ at low flow speed with a FacsCanto II cytometer (3laser, 8-color [4-2-2], BD Biosciences) using DIVA software. Fluorescent beads (Fluoresbrite Multifluorescent 1- $\mu \mathrm{m}$ microspheres, Polysciences, Germany) were added to each sample and simultaneously analysed. Stained cells were differentiated according to their green fluorescence (FL1) from SYBRGreen I staining and side-scatter properties (SSC). Picophytobenthic cells also were discriminated from heterotrophic prokaryotes by their red autofluorescence (FL3) and SSC properties and were excluded from final prokaryotic counts, measured on a gate SSC-FL1 (Marie et al., 2001). Accurate cell concentrations were performed using TruCount beads (BD-Biosciences) (excitation: red laser at $633 \mathrm{~nm}$; emission: FL5 660/20 nm). Abundances were expressed as cells per cubic centimetre or millilitre of fresh sediment (cell $\mathrm{cm}^{-3}$ or cell $\mathrm{mL}^{-1}$, respectively). 


\subsection{Meiofauna abundance}

Meiofauna abundance and group composition were obtained from three replicated cores. The top $2 \mathrm{~cm}$ of sediment from each core were preserved in absolute ethanol (vol/vol). Samples $(50 \mathrm{~mL})$ were sieved through $50 \mu \mathrm{m}$ before staining with rose Bengal and observation under a binocular loupe (Zeiss). A sample splitter (Motoda box as RzeznikOrignac et al., 2003) was used to obtain an aliquot containing at least 100 individual nematodes for the abundance estimation.

The abundance of other meiobenthic taxa (i.e., copepods and ostracodes) was too low to be evaluated in split samples and, therefore, was quantified using whole samples.Abundances were expressed as individuals percubic centimetre (ind $\mathrm{cm}^{-3}$ ) or individuals per $10 \mathrm{~cm}^{2}$ (ind $10 \mathrm{~cm}^{-2}$ ). The sizes (length and width) of nematodes were measured for at least 100 specimens picked haphazardly through a calibrated ocular micrometer. Three different size classes were made: small nematodes (mean length: $300 \pm 30$ $\mu \mathrm{m}$; mean width: $18 \pm 5 \mu \mathrm{m}$ ), medium nematodes (mean length: $695 \pm 130 \mu \mathrm{m}$; mean width: $26 \pm 9 \mu \mathrm{m}$ ), and large nematodes (mean length: $1500 \pm 160 \mu \mathrm{m}$; mean width: $75 \pm 10 \mu \mathrm{m}$ ). The biovolume was calculated using Warwick and Price (1979) formula: V=530LW², where $\mathrm{V}=$ biovolume $(\mathrm{nl})$, L=length $(\mathrm{mm})$ and $\mathrm{W}=$ width $(\mathrm{mm})$. Biovolume was then converted in biomass, considering specific density as $1.13 \mu \mathrm{g} \mathrm{nl}^{-1}$ (Wieser, 1960). The corresponding biomasses were: small nematodes: $0.07 \pm 0.001 \mu \mathrm{g}$ ind $^{-1}$, medium nematodes: $0.32 \pm 0.01 \mu \mathrm{g}$ ind $^{-1}$, and large nematodes: $5.73 \pm 0.01 \mu \mathrm{g} \mathrm{ind}^{-1}$.

From each of the three replicates, 100 nematodes were randomly withdrawn and mounted on slides in anhydrous glycerol to prevent dehydration (Seinhorst, 1959) and observed under a 100x oil immersion objective (Axioskop 2, Zeiss). All nematodes were then classified into four trophic groups according to Wieser $(1953 ; 1960)$ as follows: 1A (selective 
deposit-feeders), 1B (non-selective deposit-feeders), 2A (epigrowth-feeders), and 2B (omnivorous-carnivores).

\subsection{Statistical analysis}

In the results section, all values are presented as means $\pm \mathrm{SD}$. Variations in environmental variablesor meiofauna abundances according to the siteswere tested using Fisher tests or Wilks-Lambda tests after testingfor data normality. For non-normal data, Wilcoxon tests were applied. The relationships between environmental parameters and meiofauna were assessed by principal component analysis (PCA). Pearson's correlationswere used to measure and test the correlations between environmental variables and meiofauna. These analyses were performed with the XLSTAT 2014 software.

\section{Results}

\subsection{Environmental variables}

At Kourou, sediment was classified as fine sandy medium silt (Table 1). The Awala mudflat stations presented an alternation of three facies types: St A with very fluid mud (very soft mud) andcomposed of fine sandy silt; St Bwith moderately compacted mud (soft mud) and composed of fine silt; St Cwith compacted mud and composed of fine silt (Table 1). Warappa mudflat sediment was composed of fine silt, while Nickerie mudflats were made up of very coarse sandy fine silt (Table 1).In summary, the median grain size (MGS) among the six sampling stations ranged from 5.4 to $11.0 \mu \mathrm{m}$, and the percentage of mud in these six stations $(81.0 \%$ at Kourou, $88.76 \%$ at Awala St A, $89.65 \%$ at Nickerie, and more than $99 \%$ at Awala St B, St C and Warappa [Table 1]) was independent of the distance to the Amazon River from east to west (from French Guiana to Suriname). 
The percentage of OM massin the sediment rangedfrom $4.4 \%$ (Kourou) to $6.2 \%$ (Warappa) (Table 1). Only one value for Kourou wassignificantly differentfrom other stations (Wilcoxon, $\mathrm{p}<0.05)$.

The mean $\mathrm{Chl}$ a biomass of the top $2 \mathrm{~cm}$ of the sediment varied from 7-19 $\mu \mathrm{g} \mathrm{Chl} \mathrm{a} \mathrm{g}^{-}$ ${ }^{1}$ DW sediment (corresponding to $70-190 \mathrm{mg} \mathrm{Chl} \mathrm{a} \mathrm{m}^{-2}$ ) (Fig. 2). The Chl a biomasses were the lowestatKourou and Awala StA (large SD, no significant difference found between values, Fisher, $\mathrm{p}>0.05$ ), and the maximum $\mathrm{Chl}$ a biomass wasrecorded atAwala St B(significant difference between Kourou and Awala St B, Fisher, $\mathrm{p}<0.05$ ). Along the Awala transect, where facieswas modified between St A to St C, the Chl a biomass was greatestin the intermediate moderately compacted muddy station (St B: $18.77 \pm 1.57 \mu \mathrm{g}$ Chl a g ${ }^{-1} \mathrm{DW}$ sediment) (significant difference between the three stations at Awala, Fisher, $\mathrm{p}<0.05$ ).

Heterotrophic prokaryotic (PA) cell abundance rangedfrom $1.8-4.4 \times 10^{9}$ cells $\mathrm{mL}^{-1}$ wet sediment in the 2-cm layer (Fig. 3). Prokaryotic cell numbers were lowestat the Kourou and Awala stationsbut higher at Nickerie (significant difference, Fisher, $\mathrm{p}<0.05$ ), despitea large abundance variability $\left(4.4 \times 10^{9} \pm 1.36 \times 10^{9}\right.$ cells $\left.\mathrm{mL}^{-1}\right)$. Along the Awalatransect, prokaryotes were less abundant at St A. At St B and St C, no significant differenceswere observed (Fisher, $\mathrm{p}<0.05)$

\subsection{Meiofauna abundance}

For the entire study area, total abundances of meiobenthos ranged from about $88-220$ indcm ${ }^{-3}$ (corresponding to 1760 ind $10 \mathrm{~cm}^{-2}$ to 4400 ind $10 \mathrm{~cm}^{-2}$ at Awala St Aand Awala St C, respectively) (Fig. 4). The mean value for the six stations was 136 ind $\mathrm{cm}^{-3}$.

Along the Awala transect, a gradient of total abundances of meiobenthos appeared. The lowest abundanceswere recordedinthe very fluid mud station (St A), a medium value was recorded in the moderately compacted mud station (St B), and the highest abundanceswere 
observed in the compacted mudstation located at the edges of mangroves (St C)(significant differences between St A, B, and C at Awala, Fisher, $\mathrm{p}<0.05)$.

For all sampled stations, nematodes represented the most dominant taxon, contributing 73-92\% of total meiobenthos abundance at Awala St Aand Warappa, respectively (Figs.4 and 5). Copepods contributed $0.5-26 \%$ of the meiobenthos abundance in Warappa and Awala St A,respectively (Figs. 4 and 5). The other groups (ostracodes, plathelminthes, small bivalves, and small gastropods) accountedfora very low percentage of the meiobenthos(less than 1\%). One exception included ostracodes representing $8 \%$ of the total abundance atthe Warappa station, and, in parallel, at this same station copepods wereat very lowabundance (0.5\%).Surprisingly, no foraminifera were foundamong the six study sites.

Along the Awala transect, the percentage of nematodes increased, while the percentage of copepods decreasedfrom St A to St C (from $26 \%$ in very fluid mud to $8.7 \%$ in compacted mud before mangroves).

At all stationsexcept AwalaSt A, the size class of medium nematodes (biomass of 0.32 $\pm 0.01 \mu \mathrm{g} \mathrm{ind}^{-1}$ ) was the most dominant, contributingto $51-77 \%$ of total nematode abundance at Awala St Band Awala St C,respectively (Fig.6), with significant differences between Kourou and Awala St A, Nickerie and Awala St A, and Warappa and Awala St $\mathrm{C}(\mathrm{p}<0.05)$.Significant differences were observed for large nematodeabundances between Nickerie and Warappa $(\mathrm{p}<0.05)$. No significant difference was observed for small nematodeabundances among all stations.

Along the Awala transect, the percentage of medium nematodes increased, while the percentage of small nematodes decreased from St A to St Cfrom $44 \%$ in very fluid mud to $17 \%$ in compacted mud before mangroves (significant difference between three stations at Awala, Fisher, $\mathrm{p}<0.05)$. 
The proportion of nematodes gathered per trophic guilds was presentedin Figure7. Epigrowth-feeders (2A) were dominant in the different stations increasing in proportion through the granulometric gradient, with the lower proportion at Kourou (38\% of nematode community) and the maximum recorded at Awala St C (92\%) (significant difference, Fisher, $\mathrm{p}<0.05)$. The second dominant feeding type was non-selective deposit feeders (1B), inversely proportional to $2 \mathrm{~A}$ and ranging from 5 to $33 \%$ at Awala $\mathrm{St} \mathrm{C}$ toKourou (significant difference, Fisher, $\mathrm{p}<0.05)$. Selective deposit-feeders (1A) and omnivorous-carnivores (2B) represented an average proportion of 6 and $5 \%$, respectively. The medium and small nematodes belonged largely to epigrowth-feeders (2A) guildwhile large ones were from the 4guilds, but the omnivorous-carnivores(2B) were represented by the large nematodes.

\subsection{Relationship between environmental parameters and meiofauna}

Factor plans 1, 2, 3, and 4 of the PCA together explained97.0\% of the observed variability in each sample (Fig. 8) (axis 1: $59.8 \%$, axis 2: $18.1 \%$, axis 3: $11.0 \%$, and axis 4: 8.1\%). The variables OM content, small and large nematode abundances, and percentage of mudand sand, and the 4 feeding guildsof nematodes were represented by factor plan 1 . The variables Chl a biomass, copepod, and ostracodes abundance were represented by factor plan 2. The PAabundance was represented by factor plan 3, and medium nematode abundance was represented by factor plan 4 .

Only significant correlations were presented here and in Table 2: the OM content was positively correlated with small nematode abundance, 2A feeding type and percentage of mud, and negatively correlated with 1A feeding type, 2B feeding type and percentage of sand (Table 2; Fig. 8). The \% of mud was correlated with 2A feeding type but negatively correlated with $1 \mathrm{~A}, 1 \mathrm{~B}$ and $2 \mathrm{~B}$ feeding type and $\%$ of sand. The result of $\%$ of sand was inverted as above.Small nematode abundance was positively correlated with $2 \mathrm{~A}$ feeding type and percentage of mud but negatively correlated with $1 \mathrm{~A}$ feeding type, $2 \mathrm{~B}$ feeding type and $\%$ of 
sand. Large nematodes abundance was positively correlated with $2 \mathrm{~B}$ and $1 \mathrm{~A}$ feeding typeand percentage of sand, but negatively correlated with $2 \mathrm{~A}$ feeding type and $\%$ of mud. Moreover, copepod abundance was negatively correlated with ostracodes abundance (Table 2; Fig. 8). 1A feeding type was positively correlated with $2 \mathrm{~B}$ feeding type but negatively correlated with 2A feeding type. 1B feeding type was negatively correlated with $2 \mathrm{~A}$ feeding typeand finally, $2 \mathrm{~A}$ feeding type was negatively correlated with $2 \mathrm{~B}$ feeding type.

The PCA exposed a clear separation of different clusters corresponding to the sampling sites, driven by their abiotic and biotic parameters of the four factor plans (Fig. 8, factor plan 4 not shown).Kourou siteexhibited the lowestpercentage of mud ( $81 \%$ mud), lowest $\mathrm{OM}$ content, lowest $\mathrm{Chl}$ a biomass and the lowest nematode abundance of small one. The same station exhibited the highest percentage of sand (19\%), a part of large nematode abundance and 1A, 1B, 2B feeding type. In contrast,the Awala St B and St Cwere very muddy (100\% mud) and showed high OM content, $\mathrm{Chl}$ a biomass and the highest percentage of $2 \mathrm{~A}$ feeding type and, at St B, high abundance of small nematodes and presence of copepods. The Warappa station wasmainly represented in factor plan 2 and was characterised by the highest abundance of ostracodes andaverage Chl a biomass; it was slightly represented in factor plan 1 , characterised by a very muddy sediment and rich OM. Nickerie was represented in factor plans 2 and 3, characterised by high $\mathrm{Chl}$ a biomass and prokaryoticand copepod abundances. Awala St Awas well represented in factor plan 3, characterised by the lowest PA abundance. In addition, Awala St Aexhibited 89\% mud, the lowest Chl a biomass, the lowest prokaryotic and meiofauna abundances, but the highest proportion of small nematodes and copepods.

\section{Discussion}

The coasts of French Guiana and Suriname in South America are considered the muddiest in the world due to the enormous suspended sediment input from the Amazon River. 
Our six sampling sites were located $700 \mathrm{~km}$ (Kourou) to $1200 \mathrm{~km}$ (Nickerie) from the mouth of the Amazon River.

Our work clearly demonstrated that the distribution of the environmental parameters measured (median grainsize, OM content, Chl a biomass, and prokaryotic cell abundance) was independent of the distance of the AmazonRiver mouth among sampling sites of the four study sites.The grain size ranged from 5.4-11 $\mu \mathrm{m}$ amongthe six sampling sites,and the percentage of the mud in these six stations was independent of the distance to the AmazonRiver, from east to west (from French Guiana to Suriname).The environmental parameters probably were more influencedby the local dynamism of the migration of the mudbanks (Allison et al., 2000). Indeed, mudbanks are under strong influence of waves, tides, wind, and coastal currents, generating the movement of fluid mud, which movesmore than 1 $\mathrm{km} \mathrm{y}^{-1}$ (Allison et al., 2000). These migrant banks impose a geomorphological dynamic, leading to rapid,local changes of the shoreline(Anthony et al., 2010).In the same manner, distribution and structure of $\mathrm{Chl}$ a and meiofauna were independent of the distance to the Amazon River.Further studies are needed at a smaller scaleto measure the physical conditions of the resuspension of the sediment (i.e., bed friction velocity) (Dupuy et al., 2014; Orvain et al., 2014).

The postulated hypothesis tested was that compositions and abundances of meiofauna were different according to the grain size and particularly the fraction of fine sediment particles. In the literature, muddy sediments are characterized by high meiofaunal, and in particular, nematode abundances (Giere, 2009; Heip et al., 1985). Yamanaka et al. (2013) found an increase of meiofauna abundance with increasing particle size (183-230 $\mu$ m median particle size) on shallow-and intermediate-slope beaches. Coull (1999) argued that abundance values tend to be highest in organically enriched muds but lowest in clean sands. This postulated hypothesis is not corroborated with the present dataset, where sediments are very 
muddy, compared to the studies of Coull (1999). In fine silt sediment, meiofauna was as abundant as fine sandy medium silt or very coarse sandy fine silt.However, this hypothesis is corroborated with the different size classes of nematodes; small nematodeabundance (mainly dominated by $2 \mathrm{~A}$ feeding type)is positively correlated with higher percentage of mud (fine silt sediment) and OM content, and, inversely, large nematodeabundance (mainly dominated by 2B feeding type)is negatively correlated with higher percentage of mudand OM content. Consequently, granulometry and OM content appear to be driving factors of the size structure and functional characteristics of nematodes.Nonetheless, sediment texture is also likely to have a strong structuring influence on nematodes. Thus, in percentage, small nematodes, mainly dominated by epigrowth-feeders nematodes, are more abundant in very fluid mud (Awala St A: 44\%) compared to compacted bare mud in front ofmangroves (Awala St C: 17\%). This result could be explained by the sediment texture in Awala St A-the high fluidity of mud may result in high physical instability of the sediment (tidal currents, wave action, or input of resuspended sediment), causing a large perturbation to the settlement of the meiofauna. The lowest values of $\mathrm{Chl}$ a biomass, prokaryotes, and meiofauna abundances were recorded at Awala St A. Thus, the likely high mobility of sediment selects for smaller meiobenthic organisms and epigrowth-feeders nematodes and disturbs the larger organisms in the sediment as omnivorous-carnivorous nematodes (2B). Kapusta et al. (2005) recorded the lowest abundance of meiofauna in unstable sediment in achannel in the Tramandai-Armazem estuary in southern Brazil, and highest abundance of meiofauna, especially large species, in a sheltered area(i.e., seagrass beds). Yamanaka et al. (2013) demonstrated that the most significant factor affecting meiofauna was exposureto waves and currents.

The second postulated hypothesis was that meiofauna was more abundant when biofilm of $\mathrm{Chl}$ a and prokaryotes, both representing potential prey for meiofauna, were more abundant. This hypothesis was not corroborated with the present dataset. In this study, no 
correlation was found between meiofauna abundanceand their potential prey. The interpretation is 1) the bacterivory in meiofauna is considered a minor factor in the regulation of the prokaryote pool, andbacteria do not constitute a preferentially ingested resource (notopdown control of bacteria [Pascal et al., 2008b]); and 2) despite the fact that herbivory is largely extended in meiofauna and confirmed here by the dominance of the epigrowth-feeders (2A) in different stations, the primary production largely supplies their food needs in intertidal mudflats. Finally, meiofauna uses only a negligible part of carbon from primary production (Middelburg et al., 2000; Moens et al., 2002; Pinckney et al., 2003; Rzeznik-Orignac and Fichet, 2012; van Oevelen et al., 2006).Food availability also does not appear to limit meiofaunal abundance (no top-down control of MPB[Coull, 1999]). Furthermore, Tolhurst et al. (2010) did notfind a correlation between meiofauna and Chl a biomass. It appears that further investigations are needed to assess the primary production and meiofauna grazing rates in order to obtain reliable data of carbon flux in benthic ecosystems of the coasts of the Guianas.

Soft mudflats are characterised as containingimportant biofilms of MPB (Du et al., 2009; Herlory et al., 2004; Perkins et al., 2003; Underwood and Kromkamp, 1999; Underwood and Paterson, 2003) andhaving highmeiofaunal abundances (Heip et al., 1985) compared to sandy sediment. In the present study, in banks with muddy sediment of French Guiana and Suriname, the same tendency was found. For example, in stations with fine silt (muddy), Chl a biomass was 9-19 $\mu \mathrm{g}$ Chl a g ${ }^{-1}$ DW sedimentbut lower in stations exhibiting sandy mud(around $7 \mu \mathrm{g} \mathrm{Chl} \mathrm{a} \mathrm{g}{ }^{-1}$ DW sediment). Similar values are found in European uppershore mudflats (8.5-21 $\mu \mathrm{g}$ Chl a g ${ }^{-1}$ DW sediment[Herlory et al., 2004; Orvain et al., 2014; Underwood, 2010]), and lower values are found in sandflats of the Severn estuary (mean of 5 $\mu \mathrm{g} \mathrm{Chl} \mathrm{a} \mathrm{g}{ }^{-1}$ DW sediment[Underwood, 2010]).However, the Chl a datafromthe literature presented above wereobtained from the first 200, 500, or $1000 \mu \mathrm{m}$ of the surface 
sediment,whereas data obtained in this study correspond to the first $2 \mathrm{~cm}$ of mud. In this case, the Chl a biomassis likely tohave been diluted with sediment devoid of that used for MPB analysis. A supplementary study analysing the top $0.5 \mathrm{~mm}$ of the sediment surface in a few stations in French Guiana and Suriname showed that Chl a biomass could reach up to $180 \mu \mathrm{g}$ Chl a g ${ }^{-1}$ DW sediment in fine silt sediment (Awala St B and St C) and $80 \mu \mathrm{g} \mathrm{Chl} \mathrm{a} \mathrm{g}{ }^{-1} \mathrm{DW}$ sediment in sandy mud sediment (Kourou) (unpublished results, Dupuy, personal communication). This supplementary study demonstrated that in intertidal sandy mud sediments and fine silt sediments of French Guiana and Suriname,primary producer biomasstends to be greater thanin other tropical or European flats.

Prokaryotic abundance was within the same range as that of European mudflats $\left(2 \times 10^{9}\right.$ cellscm $^{-3}$ at Brouage (Lavergne et al., 2014; Orvain et al., 2014), and in the review of Schmidt et al. (1998), bacterial abundance remains stable, around $10^{9}$ cellscm $^{-3}$.

In our study, the meiofaunal community was constituted of only six taxaincluding small organisms of macrofauna (bivalves and gastropods). In other studies on intertidal flats, number of taxa wasvariable but in tropical area tend to welcome more taxa: inMangrove forest of Vietnam, 11 taxa were described(Xuan et al., 2007) while 7 taxa were recordedin Southeast coast of India (Chinnadurai et al., 2007). In sandy sediment of Maldives in Indian Ocean, from 17 to 20 different taxa were collected(Semprucci et al., 2010; 2011). In temperate area, the number of taxa varied from 4 to 13 taxa (Bohorquez et al., 1997 and Soetaert et al., 1995 respectively) and was similar to our results (7 taxa: Alongi et al., 1987; 6 taxa: Orignac et al., 2003).The hypothesis for explaining the lower number of taxa in tropical mudflat in French Guiana, is that mudflat is highly physically instable. Few taxa can survive in such fluid mud in the mudbanks.

On Guianas coast, total abundances of meiofaunawere particularly high, ranging from $88-220$ ind $\mathrm{cm}^{-3}$ (corresponding to 1760 ind $10 \mathrm{~cm}^{-2}$ to 4400 ind $10 \mathrm{~cm}^{-2}$ ) compared with other 
studies on intertidal flats, where abundances were lower (1000 ind $10 \mathrm{~cm}^{-2}$; Coull, 1999; Heip et al., 1985; Platt and Warwick, 1980). In the Brouage mudflats (Atlantic French coast), the mean abundances were 2000ind $10 \mathrm{~cm}^{-2}$ (Rzeznik-Orignac et al., 2003). Similar abundances previously were observed by Montagna et al. (1995) in Marennes Oléron Bay (Atlantic French coast) and by others in European estuaries, such as Gironde, Tagus, and Westerschelde (Soetaert et al., 1995), or the mudflats of the Lynher estuary in Cornwall (Warwick and Price, 1979). Abundances of meiofauna in mangrovesprovided in the literature correspond to the lower values found in our study: 1156-2082 ind $10 \mathrm{~cm}^{-2}$ in Vietnam (Xuan et al., 2007); a maximum of 735 ind $10 \mathrm{~cm}^{-2}$ in mangroves of Nha Trang Bay (Vietnam); (Mokievsky et al., 2011) and 500 ind $10 \mathrm{~cm}^{-2}$ in a tropical tidal flat of northeastern Australia (Dittman, 2000). The highest value of meiofauna abundance was found by Vanhove et al. (1992), with 6707 ind $10 \mathrm{~cm}^{-2}$ in the Bruguiera mangrovesin Gazi Bay (Kenya). In conclusion, meiofauna abundance observed in French Guiana and Suriname wasalmost always higher than in other world areas, with the exception of mangroves in Gazi Bay (Kenya) (Vanhove et al., 1992).

As a constituent of meiofauna, nematodes representthe most common and abundant taxon in this study. They are also commonly found in European Atlantic mudflats (Montagna et al., 1995; Platt and Warwick, 1980; Rzeznik-Orignac et al., 2003) and mangrove ecosystems (Alongi, 1989; Chinnadurai and Fernando, 2007; Mokievsky et al., 2011; Xuan et al., 2007). Nematodes seem to be less prominent in Cuban mangroves (Lalana-Rueda and Gosselck, 1986) and Cape York Peninsula mangrovesin Australia (Alongi, 1987).

Harpacticoid copepods are usually found asthe second-most common taxon in termsof occurrence but are present at much lower abundancescompared to nematodes in this study. Copepods are more related to coarse or sandy sediments in tropical area (Semprucci et al., 2010), or mangrove ecosystems (Chinnadurai and Fernando, 2007; Xuan et al., 2007) or in 
many European mudflats (Montagna et al., 1995; Platt and Warwick, 1980; Rzeznik-Orignac et al., 2003).

Interestingly, and, for the first time on bare mudflat habitat, no foraminifera were found among the six studied stations. Indeed, foraminifera mainly were found in the mangroves with a richness reaching up to 44 species and abundances reaching up to 2000 foraminifera50 $\mathrm{cm}^{-3}$, but they were rare or absent in the open mudbanks (Debenay et al., 2002). The hypothesis for explaining the unexpected absence of this taxa is that the high physical instability of the mudflat does not allow foraminifera to survivein such fluid mud in the mudbanks aspreviously related by Debenay et al. (2002). Nevertheless, this hypothesis must be testedby experimental approach.

Further studies in this area are neededin orderto better describe the localspecies richness of the meiofauna,and especially for nematodes. This presents a difficult challenge, since very few data from coasts of the Guianas are available, and many species will have to be described.

\section{Conclusions}

On coasts of the Guianas, in the North Atlantic coast of South America in sandy mud sediment and fine silt sediment, biomass of primary producers tended to be greater toward the other world areas, and meiofauna abundance data were almost always higher, despite the high instability of mudflats. Meiofauna was not more abundant when the sediment was composed of the finest sediment particles andalso when $\mathrm{Chl}$ aand prokaryotes, potential preys of meiofauna, were greater.But, epigrowth-feeders (2A)nematodesand small ones (biomass of $0.07 \pm 0.001 \mu \mathrm{g} \mathrm{ind}^{-1}$ ) were largelywell adapted in very fluid and unstable mud stations with probably no limitation of food source (e.g. microphytobenthos). No foraminifera were found among the six stations of the study. Very fluid mud with physical instability of sediment 
caused a large perturbation for the settlement of meiofauna; the least amounts of $\mathrm{Chl}$ a biomass and prokaryotic and meiofauna abundances were found there. Thus, the probable mobility of sediment may select for smaller meiobenthic organisms and disturb the larger organisms in the sediment, and, therefore, would not permit the settlement of foraminifera.In addition, temporary meiofauna (e.g. very small macrofauna)largely was foundin the sediment.

\section{Acknowledgments}

The authors are grateful from Sophie Maillé from GEPOG in French Guiana for the technical support, and Thierry Guyot (LIENSs laboratory) for the Map. The authors are grateful to the "Plateau microscopie" of the LIENSs laboratory of the University of La Rochelle.The work was financially supported by the CNRS and the University of La Rochelle. This research was supported through a $\mathrm{PhD}$ grant for Hien Thanh Nguyen from the USTH (University of Hanoï) of Vietnam.

\section{References}

Allison, M.A., Lee, M.T., Ogston, A.S., Aller, R.C., 2000. Origin of Amazon mudbanks along the northeastern coast of South America. Marine Geology 163, 241-256.

Alongi D.M., 1987. Intertidal zonation and seasonality of meiobenthos in tropical mangrove estuaries. Marine Biology 95, 447-458.

Alongi, D.M., 1989. The role of soft-bottom benthic communities in tropical mangrove and coral reef ecosystems. Revue Aquatic Sciences 1, 243-280. 
Anthony, E.J., Gardel, A., Gratiot, N., Proisy, C., Allison, M.A., Dolique, F., Fromard, F., 2010. The Amazon-influenced muddy coast of South America: A review of mud-bankshoreline interactions. Earth-Science Reviews 103, 99-121.

Balsamo, M., Albertelli, G., Ceccherelli, V.U., Coccioni, R., Colangelo, M.A., CuriniGalletti, M., Danovaro, R., D’Addabbo, R., Leonardis, C., Fabiano, M., Frontalini, F., Gallo, M., Gambi, C., Guidi, L., Moreno, M., Pusceddu, A., Sandulli, R., Semprucci, F., Todaro, M.A., Tongiorgi, P., 2010. Meiofauna of the Adriatic Sea: current state of knowledge and future perspectives. Chemistry and Ecology, 26: 1, 45-63.

Balsamo, M., Semprucci, F., Frontalini, F., Coccioni, R., 2012. Meiofauna as a tool for marine ecosystem biomonitoring. In: A. Cruzado (Ed) Marine Ecosystems. InTech Publisher, 4, 77-104.

Blott, S.J., Pye, K., 2001. Gradistat: a grain size distribution and statistics package for the analysis of unconsolidated sediments. Earth Surf Process Landf 26, 1237-1248.

Bohórquez, J., Papaspyrou, S., Yúfera, M., van Bergeijk, S.A., García-Robledo, E., JiménezArias, J.L., Bright, M., Corzo, A., 2013.Effects of green macroalgal blooms on the meiofauna community structure in the Bay of Cádiz. Marine Pollution Bulletin 70, 10 17.

Boucher, G., Lambshead P.J.D., 1995. Ecological biodiversity of Marine nematodes in samples from Temperate, Tropical and Deep-sea regions. Conservation Biology 9, $1594-1604$.

Chinnadurai, G., Fernando, O.J., 2007. Meiofauna of mangroves of the southeast coast of India with special reference to the free-living marine nematode assemblage. Estuarine, Coastal and Shelf Science 72, 329-336.

Coull, B.C., 1999. Role of meiofauna in estuarine soft-bottom habitats. Australian Journal of Ecology 24, 327-343 
Debenay J.P., Guiral, D., Parra, M., 2002. Ecological factors acting on the microfauna in mangrove swamps. The case of foraminiferal assemblages in French Guiana. Estuarine, Coastal and Shelf Science 55, 509-533.

Dittmann, S., 2000. Zonation of benthic communities in a tropical tidal flat of north-east Australia. Journal of Sea Research 43, 33-51.

Du, G.Y., Son, M., Yun, M., An, S., Chung, I.K., 2009. Microphytobenthic biomass and species composition in intertidal flats of the Nakdong River estuary, Korea. Estuarine, Coastal and Shelf Science 82, 663-672.

Dupuy C., Mallet C., Guizien K., Montanié H., Bréret M., Mornet F., Fontaine C., Nérot C., Orvain F., 2014. Sequential resuspension of components (virus, prokaryotes and protists) of biofilm by erodimetry experiments in the Brouage mudflat (French Atlantic coast): subsurface vertical distribution of microorganisms into the sediment. Journal of Sea Research 92, 56-65.

Heip, C., Vincx, M., Vranken, G., 1985. The ecology of marine nematodes. Oceanography and Marine Biology Annual Review 23, 399-489.

Heip, C., Huys, R., Alkemade, R., 1992. Community structure and functional roles of meiofauna in the North Sea. Netherlands Journal of Aquatic Ecology 26, 31-41.

Herlory, O., Guarini, J.M., Richard, P., Blanchard, G.F., 2004. Microstructure of microphytobenthic biofilm and its spatio-temporal dynamics in an intertidal mudflat (Aiguillon Bay, France). Marine Ecology Progress Series 282, 33-44.

Kapusta, S.C., Würdig, N.L., Bemvenuti, C.E., Ozorio, C.P., 2005. Meiofauna structure in Tramandaí-Armazém estuary (South of Brazil). Acta Limnologica Brasiliensia 17, 349359. 
Lalana - Rueda, R., Gosselck, F., 1986. Investigation of the benthos of mangrove coastal lagoons in Southern Cuba. Internationale Revue der gesamten Hydrobiologie und Hydrographie 71, 779-794.

Lavergne, C., Beaugeard, L., Dupuy, C., Courties, C., Agogué, H., 2014. An efficient and rapid method for the enumeration of heterotrophic prokaryotes in coastal sediments by flow cytometry. Journal of Microbiological Methods 105, 31-38.

Lorenzen, C.J., 1966. A method for the continuous measurement of in vivo chlorophyll concentration. Deep-Sea Research and Oceanography Abstract 13, 223-227.

Marie, D., Partensky, F., Vaulot, D., Brussaard, C., 2001. Enumeration of phytoplankton, bacteria, and viruses in marine samples. Curr Protoc CytometryJohn Wiley \& Sons, Inc.

Martinez, J.M., Guyot, J.L., Filizola, N., Sondag, F., 2009. Increase in suspended sediment discharge of the Amazon River assessed by monitoring network and satellite data. Catena 79, 257-264.

Middelburg, J.J., Barranguet, C., Boschker, H.T.S., Herman, P.M.J., Moens, T., Heip, C.H.R.,2000. The fate of intertidal microphytobenthos carbon. An in situ 13C labelling study. Limnology and Oceanography 45, 1224-1234.

Moens, T., Vincx, M., 1997. Observations on the feeding ecology of estuarine nematodes. Journal of Marine Biological Association UK 77, 211-227.

Moens, T., Luyten, C., Middelburg, J.J., Herman, P.M.J., Vincx, M., 2002. Tracing organic matter sources of estuarine tidal flat nematodes with stable carbon isotopes. Marine Ecology Progress Series 234, 127-137.

Mokievsky, V.O., Tchesunovb, A.V., Udalova, A.A., Nguen Duy T. 2011. Quantitative distribution of meiobenthos and the structure of the free living nematode community of the mangrove intertidal zone in Nha Trang Bay (Vietnam) in the South China Sea. Russian Journal of Marine Biology 37, 272-283. 
Montagna, P.A., Blanchard, G.F., Dinet, A. 1995. Effect of production and biomass of intertidal microphytobenthos on meiofaunal grazing rates. Journal Experimental Marine Biology Ecology 185, 149-165.

Orvain F., Guizien K., Lefebvre S., Bréret M., Dupuy C., 2014. Relevance of biofilm features to understand the dynamic behavior of sediment erodability and microphytobenthos resuspension. Journal of Sea Research 92, 46-55.

Pascal, P.Y., Dupuy, C., Richard, P., Haubois, A.G., Niquil, N., 2008a. Influence of environment factors on bacterial ingestion rate of the deposit-feeder Hydrobia ulvae and comparison with meiofauna. Journal of Sea Research, 60, 151-156.

Pascal, P.Y., Dupuy, C., Richard, P., Rzeznik-Orignac, J., Niquil, N., 2008b. Bacterivory of a mudflat nematode community according to biotic and abiotic factors. Marine Biology $154,671-682$.

Pascal, P.Y., Dupuy, C., Richard, P., Mallet, C., Armynot du Chatelet, E., Niquil, N., 2009. Seasonal variation in consumption of benthic bacteria by meio- and macrofauna in an intertidal mudflat. Limnology and Oceanography 54, 1048-1059.

Perkins, R.G., Honeywill, C., Consalvey, M., Austin, H.A., Tolhurst, T.J., Paterson, D.M., 2003. Changes in microphytobenthic chlorophyll a and EPS resulting from sediment compaction due to de-watering: opposing patterns in concentration and content. Continental Shelf Research 23, 575-586.

Pinckney, J.L., Carman, K.R., Lumsden, S.E., Hymel, S.N., 2003. Microalgal-meiofaunal trophic relationships in muddy intertidal estuarine sediments. Aquatic Microbial Ecology 31, 99-108.

Platt, H. M., Warwick, R. M., 1980. The significance of free living nematodes to the littoral ecosystem. In J. H. Price, D. E. G. Irvine, \& W. F. Farnham (Eds.). The shore 
environment: 2.Ecosystems, Systematics association special volume 17(b) (pp. 729759). New York: Academic Press.

Rzeznik-Orignac, J., Fichet, D., Boucher, G., 2003. Spatio-temporal structure of the nematode assemblages of the Brouage mudflat (Marennes Oléron, France). Estuarine, Coastal and Shelf Science 58, 77-88.

Rzeznik-Orignac, J., Fichet, D., 2012. Experimental estimation of assimilation rates of meiofauna feeding on C-14-labelled benthic diatoms. Journal of Experimental Marine Biology and Ecology 432, 179-185.

Semprucci F., Colantoni P., Baldelli G., Rocchi M., Balsamo M., 2010. The distribution of meiofauna on back-reef sandy platforms in the Maldives (Indian Ocean). Marine Ecology: An evolutionary perspective, 31: 592-607.

Semprucci F., Colantoni P., Sbrocca C., Baldelli G., Rocchi M., Balsamo M., 2011. Meiofauna in sandy back-reef platforms differently exposed to the monsoons in the Maldives (Indian Ocean). Journal of Marine Systems, 87: 208-215.

Schmidt, J.L., Deming, J.W., Jumars, P.A., Keil, R.G., 1998. Constancy of bacterial abundance in surficial marine sediments. Limnology and Oceanography 43, 976-982.

Schwinghamer, P., 1981. Characteristic size distributions of integral benthic communities. Canadian Journal of Fisheries and Aquatic Sciences 38, 1255-1263.

Soetaert, K., Vincx, M., Wittoeck, J., Tulkens, M., 1995. Meiobenthic distribution and nematode community structure in five European estuaries. Hydrobiologia 311, 185-206.

Tolhurst, T.J., Defew, E.C., Dye, A., 2010. Lack of correlation between surface macrofauna, meiofauna, erosion threshold and biogeochemical properties of sediments within an intertidal mudflat and mangrove forest. Hydrobiologia 652, 1-13.

Underwood, G.J.C., Kromkamp, J., 1999. Primary production by phytoplankton and microphytobenthos in estuaries. Advances in Ecological Research 29, 93-153. 
Underwood, G.J.C., Paterson, D.M., 2003. The importance of extracellular carbohydrate production by marine epiplelic diatoms. Advances in Botanical Research 40, 183-240.

Underwood, G.J.C., 2010. Microphytobenthos and phytoplankton in the Severn estuary, UK: Present situation and possible consequences of a tidal energy barrage. Marine Pollution Bulletin 61, 83-91.

van Duyl, F.C., De Winder, B., Kop, A.J., Wollenzien, U., 1999. Tidal coupling between carbohydrate concentrations and bacterial activities in diatom-inhabited intertidal mudflats. Marine Ecology Progress Series 191, 19-32.

Vanhove, S., Vincx, M., Gansbeke, D.V, Gijselinck, W., Schram, D., 1992. The meiobenthos of five mangrove vegetation types in Gazi Bay, Kenya. Hydrobiologia 247, 99-108.

van Oevelen, D., Soetaert, K., Middelburg, J.J., Herman, P.M.J., Moodley, L., Hamels, I., Moens, T., Heip, C., 2006. Quantifying intertidal food webs, using biomass, tracer and carbon isotope data. Journal of Marine Research 64, 453-482.

Warwick, R.M., Price, J.H. 1979. Ecological and metabolic studies on freeliving nematodes from an estuarine mudflat. Estuarine Coastal Marine Science 9, 257-271.

Wieser, W. 1953. Die Beziehungen zwischen Mundho“ hlengestalt, Erna“ hrungsweise und Vorkommen bei freilebenden marinen Nematoden. Eine o“ kologisch-morphologische Studie. Arkiv fur Zoologi 4, 439-484.

Wieser, W. 1960. Benthic studies in Buzzards Bay. II. The meiofauna. Limnology and Oceanography 5, 121-137.

Wollast, R., 1989. Physico-chemical models of marine sediment. Proceedings of the international seminar on the environmental aspects of dredging activities, Nantes (France). (pp. 191-204). 
Xuan Q.N., Vanreusel, A., Nguyen, V.T., Smol, N., 2007. Biodiversity of meiofauna in the Intertidal Khe Nhan Mudflat, Can Gio Mangrove Forest, Vietnam with Special Emphasis on Free Living Nematodes. Ocean Science Journal, 42, 135-152.

Yamanaka, T., Raffaelli, D., White, P.C.L., 2013. Non-Linear Interactions Determine the Impact of Sea-Level Rise on Estuarine Benthic Biodiversity and Ecosystem Processes. Plos One 8, e68160.

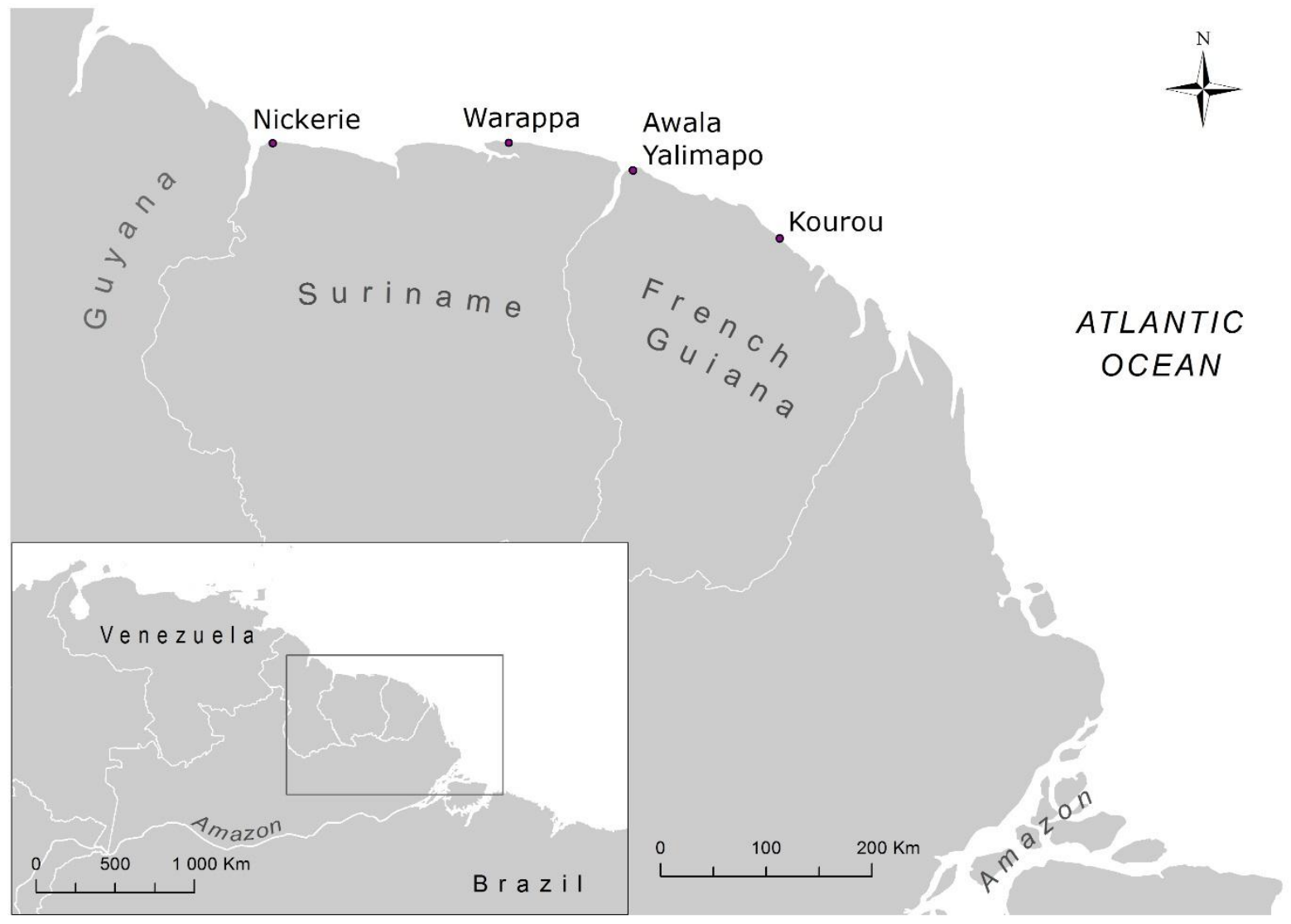

Fig. 1: Map showing the study area and location of samples collected in French Guiana and Suriname. 
25

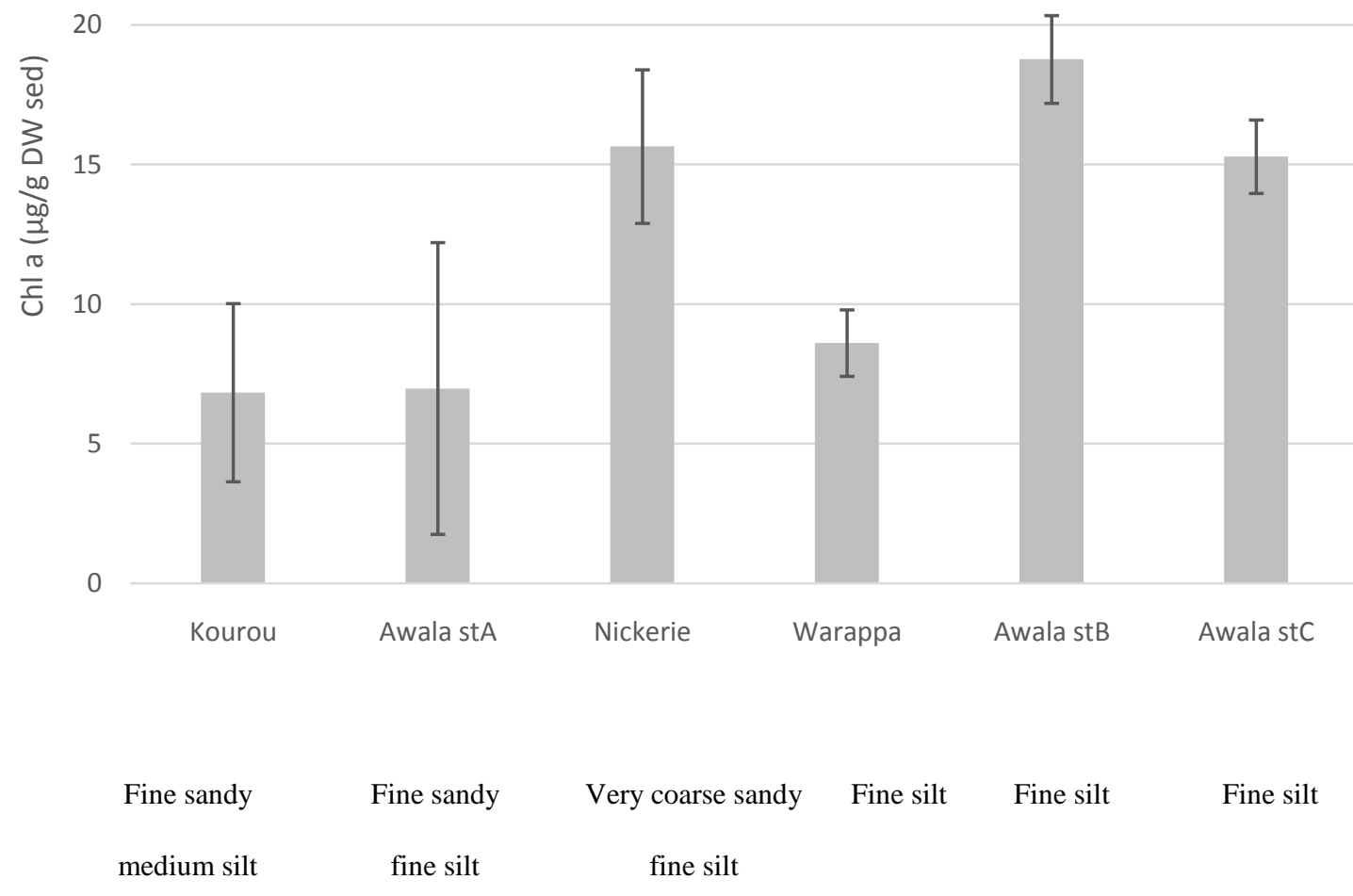

Fig. 2: Chlorophyll $a$ (Chl a) biomass (mean $\pm \mathrm{SD}$ ) of the top $2 \mathrm{~cm}$ of sediment at different stations in French Guiana and Suriname areas, classified according to sediment type. st= station. 


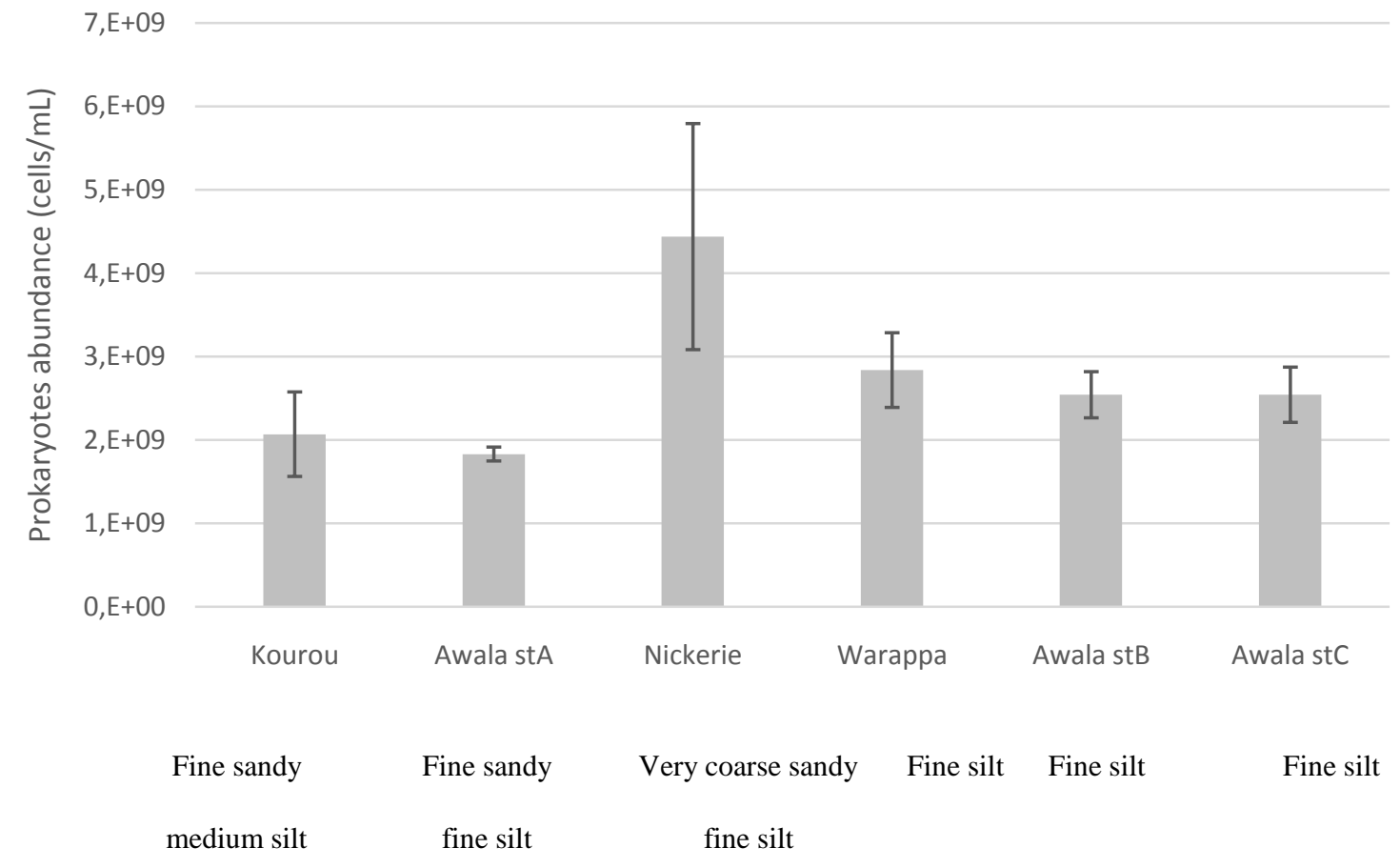

Fig. 3: Prokaryote abundance (mean $\pm \mathrm{SD}$ ) of the top $2 \mathrm{~cm}$ of sediment at different stations in French Guiana and Suriname areas, classified according to sediment type. $\mathrm{st}=$ station. 


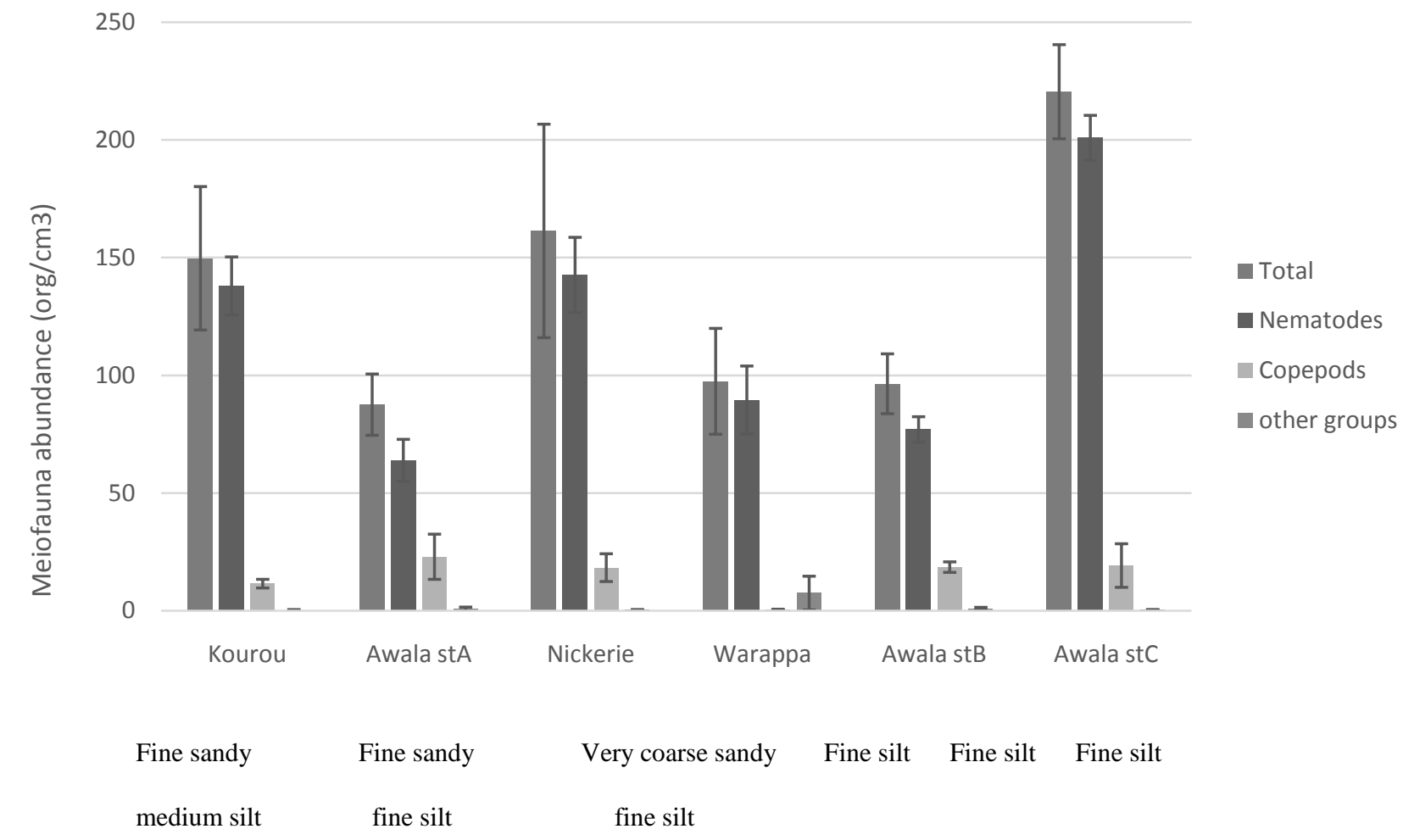

Fig. 4: Meiofauna abundance (mean $\pm \mathrm{SD}$ ) of the top $2 \mathrm{~cm}$ of sediment at different stations in French Guiana and Suriname areas, classified according to sediment type. st= station. Other groups $=$ sum of plathelminthes, ostracodes, small gastropods and small bivalves. 


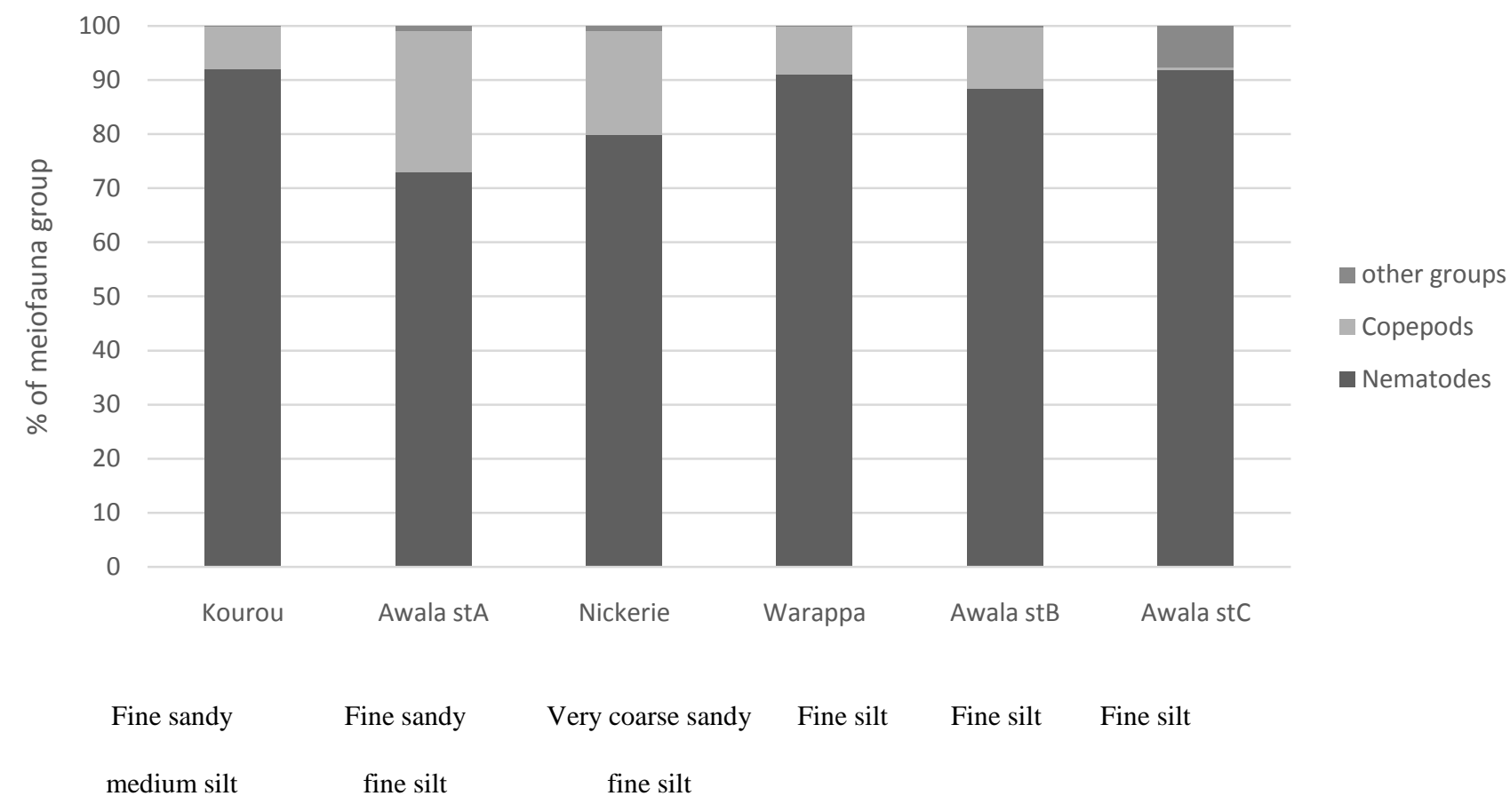

Fig. 5: Percentage of meiofauna group at different stations in French Guiana and Suriname areas, classified according to sediment type. $s t=$ station. $\%=$ percentage. Other groups $=$ sum of plathelminthes, ostracodes, small gastropods and small bivalves. 


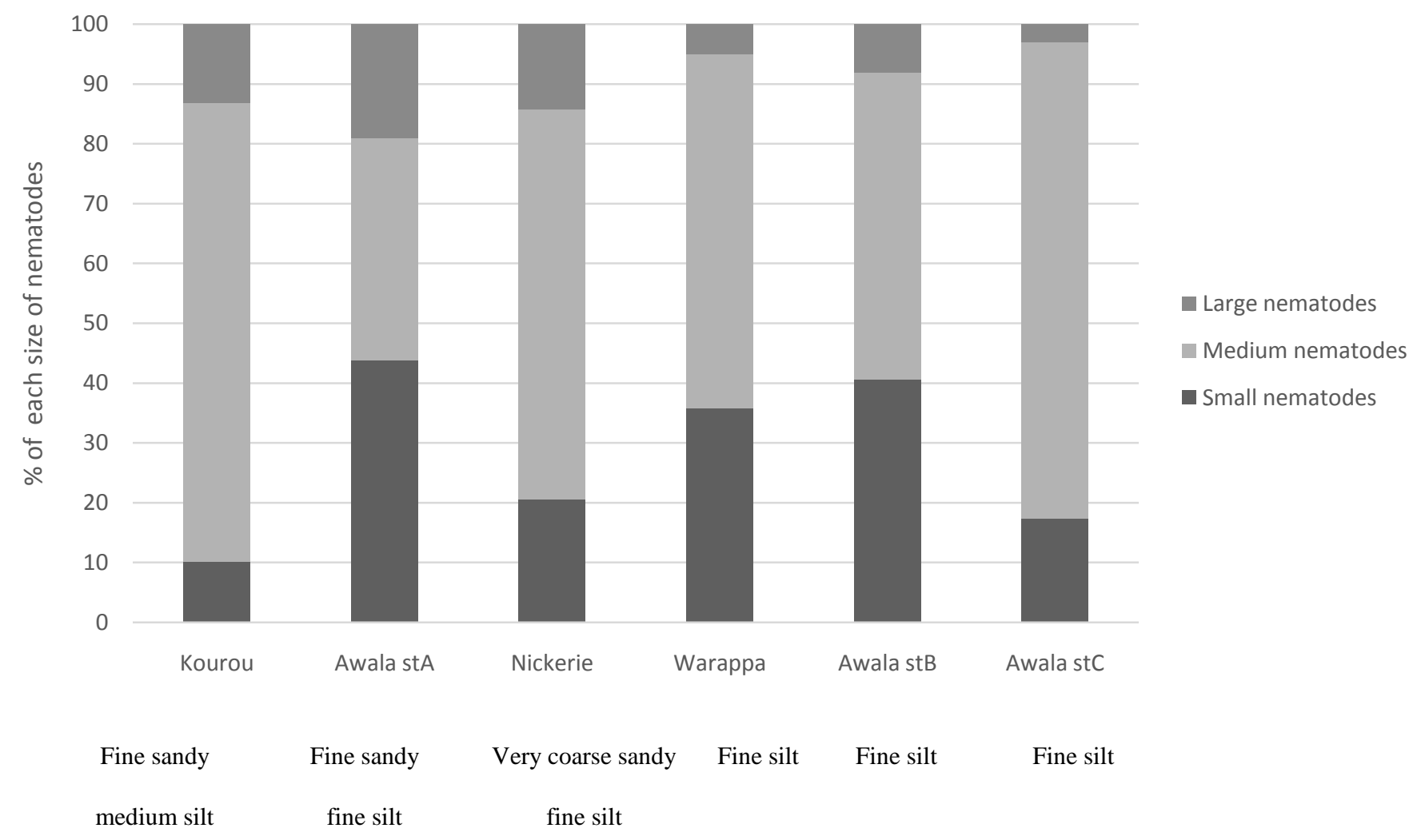

Fig. 6: Percentage of the size classes of nematodes at different stations in French Guiana and Suriname areas, classified according to sediment type. Classifications were as follows: small nematodes (mean length: $300 \pm 30 \mu \mathrm{m}$; mean width: $18 \pm 5 \mu \mathrm{m}$ ); medium nematodes (mean length: $695 \pm 130 \mu \mathrm{m}$; mean width: $26 \pm 9 \mu \mathrm{m}$ ); and large nematodes (mean length: $1500 \pm$ $160 \mu \mathrm{m}$; mean width: $75 \pm 10 \mu \mathrm{m}$ ). st= station. \%= percentage. 


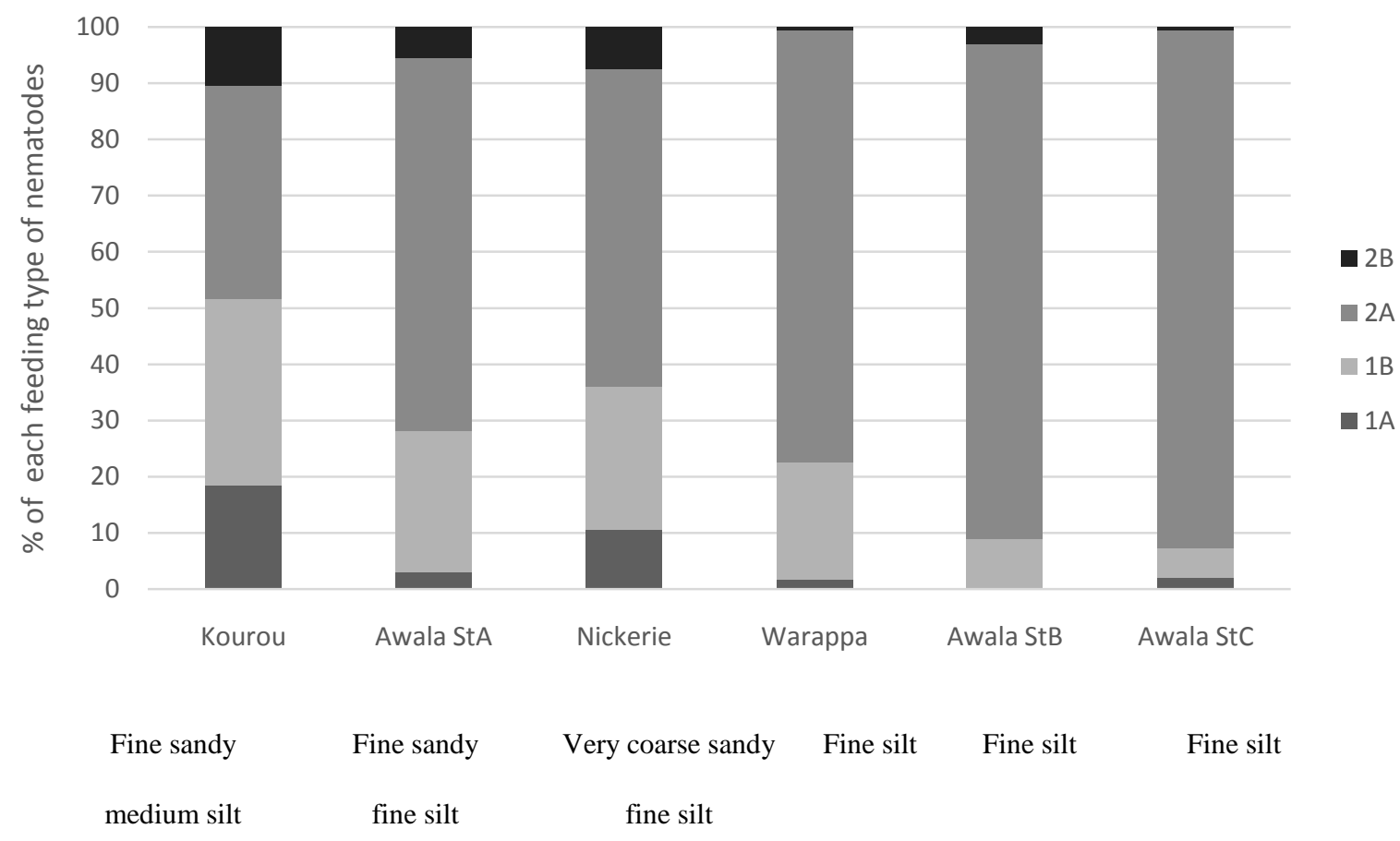

Fig. 7: Percentage of each feeding type of nematodes at different stations in French Guiana and Suriname areas, classified according to sediment type. 1A, selective deposit feeders; 1B, non-selective deposit feeders; $2 \mathrm{~A}$, epigrowth feeders; $2 \mathrm{~B}$, omnivorous-carnivorous. $\mathrm{st}=$ station. $\%=$ percentage. 
A

Biplot (axes F1 and F2 : $77.88 \%$ )

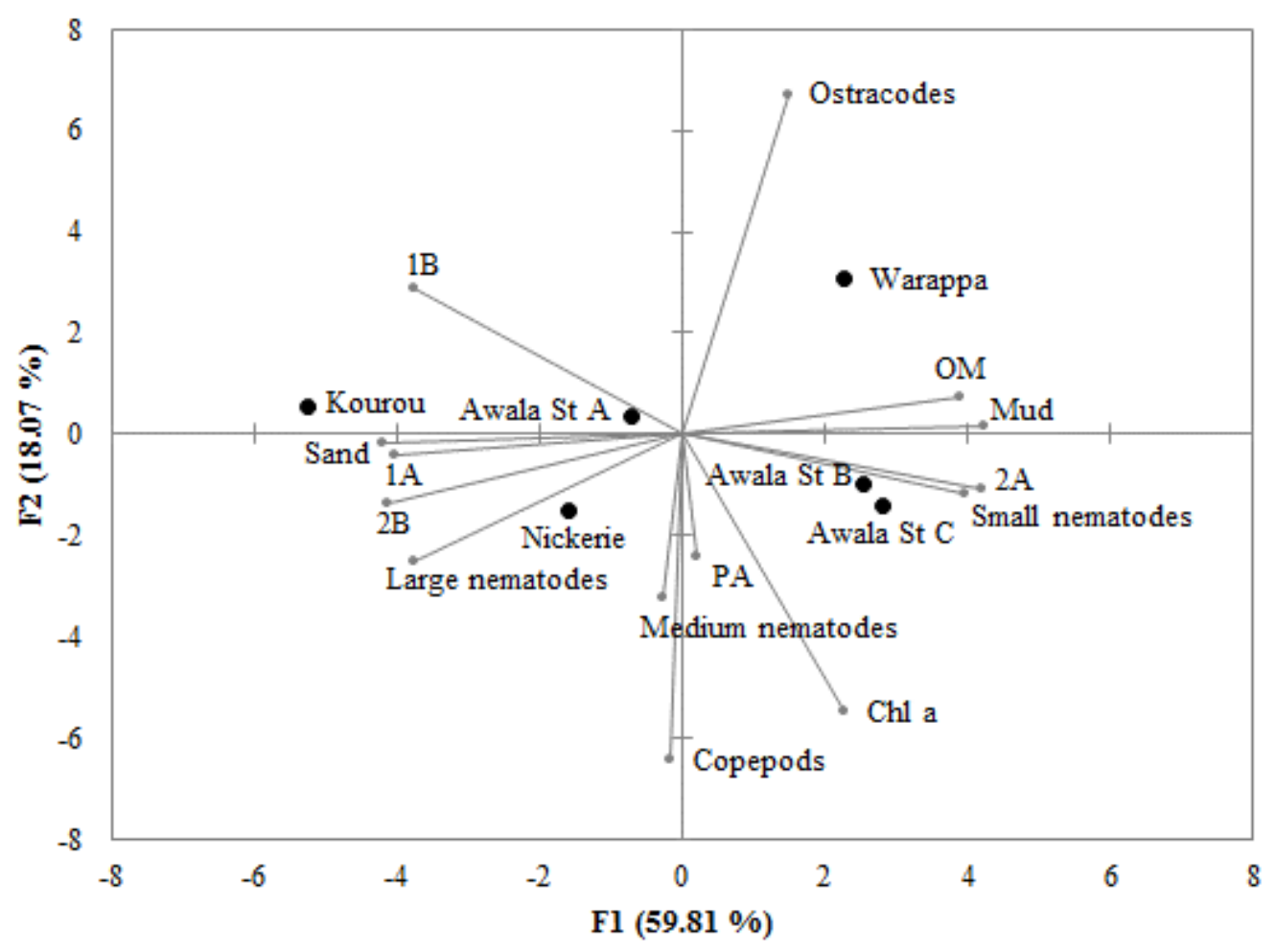

B

Biplot (axes F1 and F3 : $70.81 \%$ )

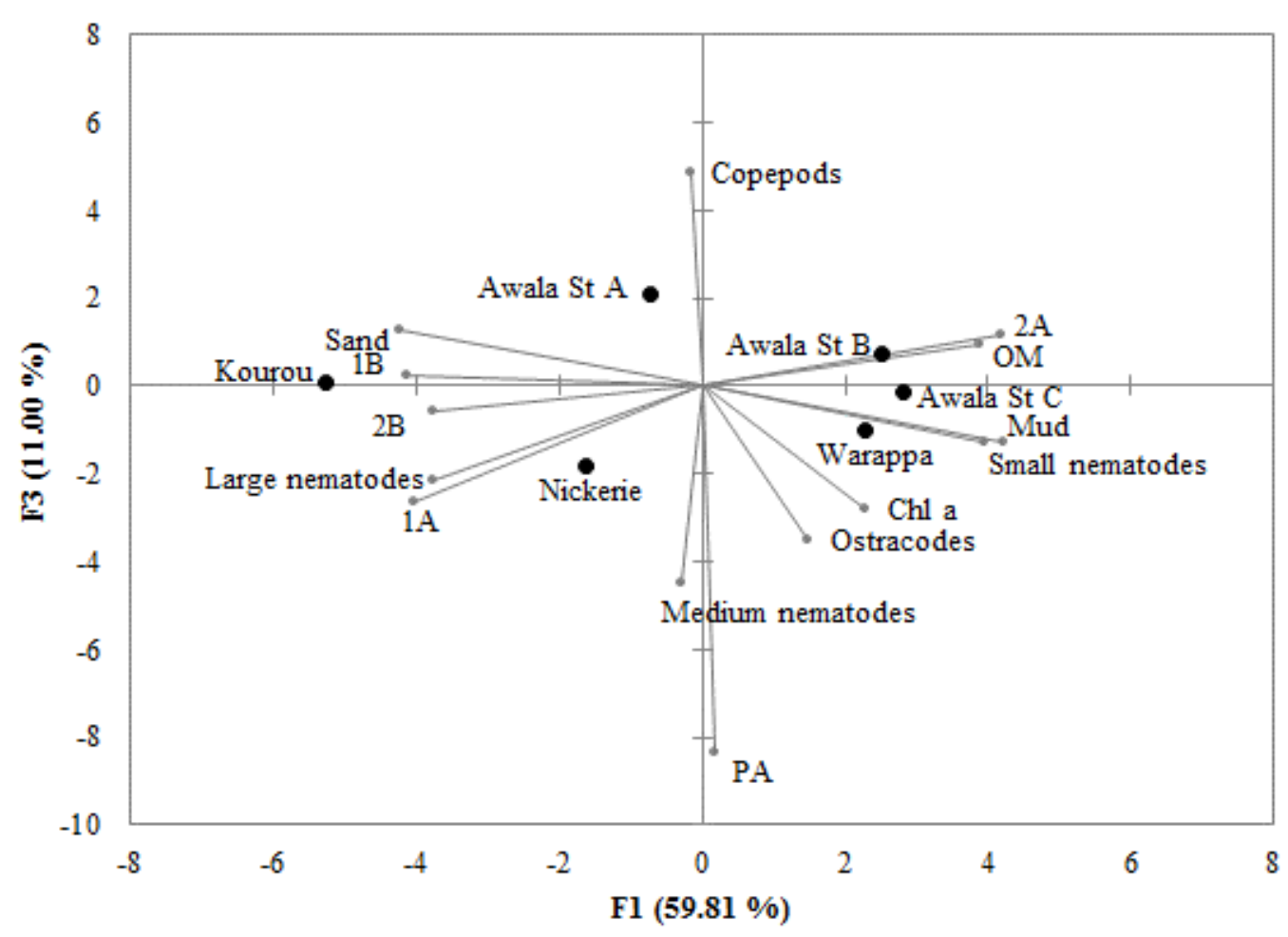


Fig. 8: Principle component analyses calculated using six observations (samples of six sites: Kourou, Nickerie, Warappa, and Awala Stations A, B, and C) and 14 variables (mud, sand, OM, PA, Chl a, small, medium, and large nematods, copepods, and ostracodes abundance, and the 4 feeding type of nematodes). A) Biplot F1 $\times$ F2 and B) biplot F1 $\times$ F3. For each variable, the circle of correlation is reported. Observations were reported in the circle of correlation. Abbreviations: $\mathrm{Chl}$ a: chlorophyll $a$ biomass; mud: percentage of mud; sand: percentage of sand; OM: organic matter mass; PA: prokaryotic cell numbers; 1A, 1B, 2A and 2B: feeding guilds of nematodes (see material and methods part for details); $s t=$ station. 
Table 1: Granulometric parameters and organic matter content $(\mathrm{OM})(\%)$ of the different stations in French Guiana and Suriname areas.

\begin{tabular}{|l|c|c|c|c|c|c|c|c|}
\hline \multicolumn{1}{|c|}{ Station } & Mud (\%) & Sand (\%) & $\begin{array}{c}\text { Mean grain } \\
\mathbf{s i z e}(\boldsymbol{\mu m})\end{array}$ & $\begin{array}{c}\text { Median } \\
\text { grain size } \\
(\boldsymbol{\mu m}) \text { D 50 }\end{array}$ & Sample type & $\begin{array}{c}\text { Textural } \\
\text { group }\end{array}$ & $\begin{array}{c}\text { Sediment } \\
\text { name }\end{array}$ & OM (\%) \\
\hline Kourou & 81 & 19 & 14.08 & 10.96 & Bimodal & Sandy mud & $\begin{array}{c}\text { Fine sandy } \\
\text { medium silt }\end{array}$ & 4.44 \\
\hline Awala St1 & 88.76 & 11.24 & 7.96 & 5.86 & Bimodal & Sandy mud & $\begin{array}{c}\text { Fine sandy } \\
\text { fine silt }\end{array}$ & 5.99 \\
\hline Nickerie & 89.65 & 10.35 & 9.75 & 6.54 & Bimodal & Sandy mud & $\begin{array}{c}\text { Very coarse } \\
\text { sandy fine silt }\end{array}$ & 5.55 \\
\hline Warappa & 99.78 & 0.22 & 5.45 & 5.15 & Unimodal & Mud & Fine silt & 6.21 \\
\hline Awala St4 & 99.92 & 0.08 & 5.62 & 5.51 & Unimodal & Mud & Fine silt & 6 \\
\hline Awala St5 & 100 & 0 & 5.48 & 5.45 & Unimodal & Mud & Fine silt & 5.99 \\
\hline
\end{tabular}


Table 2: Pearson's correlations and p-values between environmental variables and meiofauna. $\mathrm{PA}=$ Prokaryotes abundance; $\mathrm{Chl} \mathrm{a}=$ Chlorophyll a biomass; $1 \mathrm{~A}, 1 \mathrm{~B}, 2 \mathrm{~A}$ and $2 \mathrm{~B}$; feeding guilds of nematodes (see material and methods part for details).

Pearson's correlation

\begin{tabular}{|c|c|c|c|c|c|c|c|c|c|c|c|c|c|c|}
\hline Variables & PA & $\begin{array}{c}\text { Chl } \\
\text { a }\end{array}$ & OM & $\begin{array}{c}\text { Small } \\
\text { nemat } \\
\text { odes }\end{array}$ & $\begin{array}{c}\text { Medium } \\
\text { nematodes }\end{array}$ & $\begin{array}{c}\text { Large } \\
\text { nematod } \\
\text { es }\end{array}$ & $\begin{array}{c}\text { Copepod } \\
\text { s }\end{array}$ & $\begin{array}{c}\text { Ostracod } \\
\text { es }\end{array}$ & Mud & Sand & $1 \mathrm{~A}$ & 1B & $2 \mathrm{~A}$ & 2B \\
\hline PA & 1 & - & - & - & - & - & - & - & - & - & - & - & - & - \\
\hline Chl a & & 1 & - & - & - & - & - & - & - & - & - & - & - & - \\
\hline OM & & & 1 & 0.935 & - & - & - & - & 0.847 & -0.847 & -0.96 & - & 0.851 & $\begin{array}{c}- \\
0.872\end{array}$ \\
\hline $\begin{array}{l}\text { Small } \\
\text { nematodes }\end{array}$ & & & & 1 & - & - & - & - & 0.894 & -0.894 & -0.884 & - & 0.893 & $\begin{array}{c}- \\
0.875\end{array}$ \\
\hline $\begin{array}{l}\text { Medium } \\
\text { nematodes }\end{array}$ & & & & & 1 & - & - & - & - & - & - & - & - & - \\
\hline $\begin{array}{l}\text { Large } \\
\text { nematodes }\end{array}$ & & & & & & 1 & - & - & -0.871 & 0.871 & 0.848 & - & -0.865 & 0.921 \\
\hline Copepods & & & & & & & 1 & -0.882 & - & - & - & - & - & - \\
\hline Ostracodes & & & & & & & & 1 & - & - & - & - & - & - \\
\hline Mud & & & & & & & & & 1 & -1 & -0.883 & $\begin{array}{l}- \\
0.8 \\
77\end{array}$ & 0.952 & $\begin{array}{c}- \\
0.954\end{array}$ \\
\hline Sand & & & & & & & & & & 1 & 0.883 & $\begin{array}{l}0.8 \\
77\end{array}$ & $\begin{array}{l}-0.952 \\
\end{array}$ & 0.954 \\
\hline 1A & & & & & & & & & & & 1 & - & -0.927 & 0.894 \\
\hline 1B & & & & & & & & & & & & 1 & $\begin{array}{l}-0.95 \\
\end{array}$ & - \\
\hline $2 \mathrm{~A}$ & & & & & & & & & & & & & 1 & $\begin{array}{c}- \\
0.928\end{array}$ \\
\hline
\end{tabular}

P-Values

\begin{tabular}{|c|c|c|c|c|c|c|c|c|c|c|c|c|c|c|}
\hline Variables & PA & $\begin{array}{c}\text { Chl } \\
\text { a }\end{array}$ & OM & $\begin{array}{c}\begin{array}{c}\text { Small } \\
\text { nemat } \\
\text { odes }\end{array} \\
\text {. }\end{array}$ & $\begin{array}{c}\text { Medium } \\
\text { nematodes }\end{array}$ & $\begin{array}{c}\text { Large } \\
\text { nematod } \\
\text { es }\end{array}$ & $\begin{array}{c}\text { Copepod } \\
\text { s }\end{array}$ & $\begin{array}{c}\text { Ostracod } \\
\text { es }\end{array}$ & Mud & Sand & $\mathbf{1 A}$ & 1B & $2 \mathrm{~A}$ & $2 \mathrm{~B}$ \\
\hline PA & 0 & - & - & - & - & - & - & - & - & - & - & - & - & - \\
\hline Chl a & & 0 & - & - & - & - & - & - & - & - & - & - & - & - \\
\hline OM & & & 0 & 0.006 & - & - & - & - & 0.033 & 0.033 & 0.002 & - & 0.031 & 0.023 \\
\hline $\begin{array}{l}\text { Small } \\
\text { nematodes }\end{array}$ & & & & 0 & - & - & - & - & 0.016 & 0.016 & 0.019 & - & 0.016 & 0.022 \\
\hline $\begin{array}{l}\text { Medium } \\
\text { nematodes }\end{array}$ & & & & & 0 & - & - & - & - & - & - & - & - & - \\
\hline $\begin{array}{l}\text { Large } \\
\text { nematodes }\end{array}$ & & & & & & 0 & - & - & 0.024 & 0.024 & 0.033 & - & 0.026 & 0.009 \\
\hline Copepods & & & & & & & 0 & 0.019 & - & - & - & - & - & - \\
\hline Ostracodes & & & & & & & & 0 & - & - & - & - & - & - \\
\hline Mud & & & & & & & & & 0 & $<0.0001$ & 0.019 & $\begin{array}{l}0.0 \\
21\end{array}$ & 0.003 & 0.003 \\
\hline Sand & & & & & & & & & & 0 & 0.019 & $\begin{array}{l}0.0 \\
21\end{array}$ & 0.003 & 0.003 \\
\hline $\mathbf{1 A}$ & & & & & & & & & & & 0 & - & 0.007 & 0.016 \\
\hline 1B & & & & & & & & & & & & 0 & 0.003 & - \\
\hline $2 \mathrm{~A}$ & & & & & & & & & & & & & 0 & 0.007 \\
\hline
\end{tabular}


